A. V. Kosenko, orcid.org/0000-0003-3058-4820
Institute of Physics of Mining Processes of the National Academy Sciences of Ukraine, Dnipro, Ukraine, e-mail: AndreyVladimirovich@email.ua

\title{
IMPROVEMENT OF SUB-LEVEL CAVING MINING METHODS DURING HIGH-GRADE IRON ORE MINING
}

Purpose. To improve of the sub-level caving mining methods during mining of deposits of high-grade iron ores by applying a rational mode and intensifying the ore drawing.

Methodology. It included an analysis of scientific literature, design documentation and the practice of mining of deposits of high-grade iron-ores in complex geomechanical conditions of deep horizons of mines, to establish the formation of fundamentally new foundations of scientific-and-design solutions for the rational extraction of minerals; numerical (application a special computer software package "PFC 3D") and physical (based on the application of volumetric physical models and equivalent materials) modeling of ore drawing, aimed at identifying regularities of recovery process depending on the mining-geological and mining conditions of the mining of deposits, and also the physical- and-mechanical properties of the loosened ore mass.

Findings. Regularities of changes in the qualitative and quantitative recovery percentages depending on the intensity of the ore drawing and physical-and-mechanical properties of the ore have been established using numerical and physical simulation. The obtained regularities made it possible to substantiate the rational parameters of the structural elements of the technological scheme for drawing and delivery of ore. A linear-alternating condition of ore drawing was developed, which will ensure an increase in the extraction of pure ore up to $10 \%$ and, as a result, up to $4.6 \%$ of quantitative and up to $5.2 \%$ of qualitative indicators of ore percentages, as well as up to $1.5 \%$ of absolute quality of mined ore mass.

Originality. Power-law dependencies of the change in the angle of ore tapping on the intensity of the ore drawing and the ultimate strength of the ore for uniaxial compression have been established as well as dependencies of the increase in the volume of the tapping figure, when a linear-alternating condition of ore drawing is applied, on the intensity of the ore drawing, the height of the collapsed ore layer and the ultimate strength of the ore for uniaxial compression.

Practical value. A linear-alternating condition of ore drawing has been developed, the implementation of which in practice makes it possible to increase the qualitative and quantitative recovery percentages and eliminate the human factor while observing the ore drawing planograms.

Keywords: high-grade iron ores, sub-level caving, recovery percentages, ore losses, dilution, ore drawing, physical modeling, numerical modeling

Introduction. Ukraine ranks third in the world in terms of proven reserves of high-grade iron ores, which account for about $9.7 \%$ of total world reserves [1]. The main part of the rich iron-ores reserves of Ukraine is concentrated in the Kryvorizskyi basin (more than 1.6 billion tons) [2], which determines the special importance of mining enterprises in Kryvyi Rih in the economy of our country totally. Since the mining industry of Ukraine is one of the main sectors of the country's budget, and the application of modern mechanisms of state regulation and integrated development of the mineral resource base of the basin will ensure the competitiveness of the national economy [3]. Development of high-grade iron ores deposits of the Kryvorizskyi iron-ore basin is conducted by three mining enterprises: PJSC "Kryvorizskyi Iron-Ore Plant"; PJSC "Sukha Balka”; PJSC "ArcelorMitttal Kryvyi Rih", which extract $73 \%$ of all reserves of high-grade ironores in Ukraine (part of the production of $27 \%$ falls on PJSC "Zaporizskyi Iron Ore Plant"). At the same time, the export of iron-ore in the world market is only $2.5 \%$ of the total world sales, due to much lower quality of ore, compared to Australia, Brazil, South Africa and Canada [1]. This is due to the fact that the extraction of high-grade iron-ore in the underground Kryvbas is carried out at depths of 1100-1400 m under the action of the vertical component of rock pressure, with a larger scale, about $51.4 \%$, with the application of a system of subsurface collapse with bottom ore and application of stationary and portable mining equipment, which in connection with the lowering of the level of stoping operations is becoming even more widespread. These mining methods are characterized by a long period of preparatory operations (4-6 months) and mining of stoping panels (3.5-5 months) and, as a consequence, two- or three-fold re-bolting of mine workings and drilling of $30-40 \%$ of deep boreholes, insufficient breaking process, the volume of compensation chambers (up to $20 \%$ ),

(C) Kosenko A. V., 2021 ore losses in the range of $17-25 \%$ and ore admixture in the range of $14-18 \%$ of waste rocks. Such indicators of extraction of reserves of mining units do not meet modern requirements for the rational mining of deposits of high-grade iron-ores. Therefore, further mining of iron-ore deposits by well-known variants of subsurface collapse systems will not contribute to the improvement of technical-and-economic indicators of mining operations on deep horizons.

Literature review. The main technological process that forms the indicators of ore extraction involves the drawing and delivery, which are currently the most imperfect and timeconsuming types of operations [4]. The drawing from adjacent mine workings is conducted in successive equal doses according to the planograms to reduce losses and depletion of reflected ore. However, the existing drawing methods do not provide the performance of planograms due to the constant hanging of ore pieces inset the drawing workings. As a result, the production process is delayed and accompanied by high rates of losses and dilution, which significantly exceed the normative (losses $-14-18 \%$, contamination- $12-16 \%$ ).

Research works by such domestic and foreign scientists as Agoshkov M.I., Abramov V.F., Baron L.I., Wolfson P. M., Dubinin N. G., Imenitov V. R., Korzh V.A., Kudriavtsev M. I., Kulikov V.V., Malakhov G. M., Chernenko A. R., Chernenko V.A., Brown E.T., Castro R. L., Chitombo G.P., Pierce M.E. are devoted to establishing rational parameters of subsurface collapse systems and patterns of movement of a flowing medium. However, in their works, the main attention is paid to the influence of a number of constructive and technological parameters of these mining methods on quantitative and qualitative indicators of ore extraction. Among them there are geometric dimensions of mining blocks; designs and diameters of drawing workings; distances between drawing and delivery workings; the height of the drawn ore layer; particle size distribution of the collapsed ore mass; sequence and size of drawing doses. 
Practical experience and research, which include methods of laboratory modeling, theoretical generalizations and mine experiments have shown that the rational parameters of the ore drawing process in the subsurface collapse system depend on the initial geomechanical state of the crushed ore mass of the extraction unit and regularities of its changing in production; particle size distribution of ore and collapsed rocks; physical and deformation characteristics of ore; sequence and volume of doses of ore from drawing workings; the intensity of the technological process of drawing [5].

Unsolved aspects of the problem. The calculation of drawing process parameters is conducted according to the theory of Malakhov G. M. (1969), which is the main one and, unfortunately, does not take into account the intensity of the drawing process, physical and mechanical properties of the ore and mining depth. Therefore, improving the system of subsurface collapse on the basis of establishing regularities of ore extraction changing parameters of structural elements of the receiving horizon bottoms from the intensity and mode of the drawing process is an urgent and economically important scientificand-practical task and has great commercial importance [6].

Purpose. The purpose of the work is to improve the systems of subsurface collapse of ore and associated rocks during mining of high-grade iron-ores deposits by applying a rational mode and intensification of the technological process of drawing.

Methods. Numerical simulation of ore drawing was conducted with the application of the software package "PFC 3D". Initial and boundary conditions were determined for the operation of the numerical model. The ore mass was represented in the form of a discrete medium which consists of a set of individual pieces with different geometric parameters and physical-and-mechanical properties that interact between each other. Particle size distribution for modeling is defined as the arithmetic value of collapsed reserves of high-grade ores alongside the mines of the Kryvbas (Table 1).

Since the methods of dispersing analysis in most cases do not allow one to fully characterize each particle of the dispersed system in three dimensions, so the particles of real material were replaced by equivalent particles of the correct geometric shape. Then the nature was determined of the interaction between the particles of the discrete material, which have five types of interaction between the particles, according to the laws of classical Newton's mechanics.

Due to the fact that the discrete medium has no adhesion forces but has internal friction, and at different mines of the Kryvbas ore is characterized by a variety of strength of uniaxial contact, which varies on average from 40 to $100 \mathrm{MPa}$, according to Coulomb's law, the internal friction angles, which influence the parameters of the drawing figure and vary in the range from 40.5 to $53.0^{\circ}$ were established.

Also, the value of rock pressure at a depth of mining operations of 1400-1500 m for averaged mining-and-geological conditions were laid into the model. After selecting an equivalent computer system, the model was uploaded.
The conditions of the second class of mining with a seam thickness of $60 \mathrm{~m}$ at a depth of mining operations of $1400 \mathrm{~m}$, stoping panels with a length of $25 \mathrm{~m}$ and cross extension of the ore deposit with $25 \mathrm{~m}$ were simulated. The discrete medium for each experiment was set into the model with different density indices $\left(K_{o}=1-1.4\right)$, simulating the explosive reflection of an ore mass of different strength on the compensation space with a volume of $25 \%$. During the simulation the following was also changed: the intensity of ore production through the drawing mine workings in the range from 1.5 to $10.5 \mathrm{t} / \mathrm{m}^{2}$ per day with an interval of 0.5 ; the number of drawing workings, with an interval from 1 to 4 .

Research on physical modeling of ore drawing process was conducted for mining-and-geological and mining conditions of mining extraction units of layered medium thickness and thick ore bodies in the laboratory of ore production on the base of Institute of Physics of Mining Processes of the National Academy of Sciences of Ukraine (NASU).

To obtain correct results in the process of physical modeling of ore mass production, in accordance with the method by professor Imenitov V. R., it is necessary and sufficient to ensure the functional similarity of a model and the nature, namely: similarity of geometric properties of model and nature systems; similarity of processes in modeling and in kind, which must be described by identical differential equations; similarity of the initial state of the systems; similarity of conditions at the boundaries of systems during the whole considered period of the process; equality of defining criteria included in the differential equations in the model and the nature.

The main characteristics of functionality that indicate the similarity of the model and nature systems are the parameters of the drawing figure, area and number of hangs, the height of the outlet seam, deflection and diameter of the hopper, i.e. the similarity of processes by basic technological functions, including requirements for equivalent material [7].

Selection of equivalent material according to the method by Professor Kuznetsov G. N. must provide conditions for mechanical similarity of model and nature and corresponds to the ratio

$$
N_{m}=\frac{L_{m}}{L_{n}} \cdot \frac{\gamma_{m}}{\gamma_{n}} \cdot N_{n}
$$

where $N_{n}$ and $N_{m}$ are, respectively, the numerical values of the mechanical properties of the simulated rocks and equivalent material; $L_{n}$ and $L_{m}$ are, respectively the linear dimensions of the nature and model; $\gamma_{n}$ and $\gamma_{m}$ are, respectively, the bulk density of the material and rocks being modeled.

In order to facilitate the task of similarity from the equivalent material of the model, it is possible to exclude particles of fractional composition less than $1 \mathrm{~mm}$, thus, the similarity conditions will be limited to the correspondence of the internal friction angle of the bulk body in the nature and on the model. This will avoid violating the geometric similarity of the ore drawing process in the space of the stoping unit, as in kind

Table 1

Distribution of granulometric composition of breaking ore by fractions at mines of the Kryvorizskyi basin

\begin{tabular}{|l|c|c|c|c|c|}
\hline \multirow{2}{*}{ Name of the mine } & \multicolumn{5}{c|}{ Mass yield of fractions (\%), dimensions, $\mathrm{mm}$} \\
\cline { 2 - 7 } & $0-10$ & $10-25$ & $25-50$ & $50-100$ & $>100$ \\
\hline Mine Management "ArcelorMitttal Kryvyi Rih" & 51.8 & 18.1 & 9.9 & 6.8 & 13.4 \\
\hline "Batkivschyna" & 54.1 & 9.8 & 10.5 & 7.9 & 17.7 \\
\hline "Zhovtneva" & 53.2 & 11.9 & 11.2 & 8.6 & 15.1 \\
\hline "n.a. Frunze" & 57.0 & 10.8 & 10.7 & 7.7 & 13.8 \\
\hline "Yuvileina" & 51.3 & 11.0 & 12.1 & 7.8 & 17.8 \\
\hline "Hvardiiska" & 55.1 & 10.3 & 12.2 & 8.9 & 13.5 \\
\hline "Ternivska" & 54.4 & 14.1 & 11.1 & 7.7 & 12.7 \\
\hline Average value & $\mathbf{5 3 . 8}$ & $\mathbf{1 2 . 3}$ & $\mathbf{1 1 . 1}$ & $\mathbf{7 . 9}$ & $\mathbf{1 4 . 9}$ \\
\hline
\end{tabular}


the ore mass of the fractional composition less than $100 \mathrm{~mm}$ has little effect on the nature of ore movement during production, in this case only the friction forces act on the ore, for an unconnected medium with a coefficient of adhesion $k=0$. The similarity of deformation can also be excluded from the physical modeling due to the insignificant effect of short-term static load on the compression of the reflected ore $[8,9]$.

Therefore, the selection of equivalent material can be based on the ratio

$$
\frac{H}{h}=\frac{D}{d}=\frac{Z}{z}=\sqrt[3]{\left(\frac{V}{v}\right)}=C_{L},
$$

where $H, h$ is the thickness of the seam of backfilled material, respectively, in the nature and in the model; $D, d$ is the diameter of the deflection, respectively, in the nature and model; $Z$, $z$ is the depth of deflection, respectively, in the nature and model; $V, v$ is volume drawing in the nature and on the model; $C_{L}$ is linear scale.

As a bulk material for the examination of the ore drawing process in accordance with the criteria of similarity and recommendations $[10,11]$ the crushed magnetite ore (section by fractions: $+0.5-1-5.3 \% ;+1-2-27.8 \% ;+2-3-26.2 \%$; +3$5-40.7 \%$ ) and crushed granite (fraction $+5-7-100 \%$ ) is applied. Based on the experience of conducting laboratory examinations on physical models with application of equivalent materials, the scale of modeling is taken as $1: 100$ [12].

According to the chosen scale of modeling, a three-dimensional physical model was chosen, which reflects the cleaning panel and is a three-dimensional figure, the scheme and detailed description of which is given in work [13].

The modeling technique included determining the amount of pure ore in the process of its drawing from four adjacent mine workings, which lie on the same axis, at the same time in uniform doses with the same frequency. This mode of issue was called linear-alternating.

The research was performed for the development of a deposit of high-grade iron-ore with a thickness of $25 \mathrm{~m}$, stoping panels with $40 \mathrm{~m}$ of height and a length of $25 \mathrm{~m}$. After filling the model, pure ore was produced before the start of crushed granite to simulate the horizontal contact of the reflected ore massif and collapsed waste rocks. After filling the model, pure ore was drawn before the yield of crushed granite.

In the course of physical modeling, the drawing of several (2-4) adjacent mine workings was studied, which lie on the same axis, at the same time in uniform doses with the same periodicity (the linear-alternating mode of release) at different sequencing of exhaust linear zones (from lying to hanging side and on the contrary) ore drawing through funnels of different diameters and different distances between them, with a change in the angle of inclination of the side wall of the model, simulating the lying side of the ore deposit.

For establishing the qualitative dependencies of the improvement of ore extraction rates, the developed drawing mode was compared with a uniform-consistent one, which provides the best extraction rates in comparison with other existing drawing modes. The reliability of the obtained results is confirmed by the fact that in the process of research on the model a constant particle size distribution of ore and waste rock was applied. To determine the accuracy of the obtained results, the corresponding coefficients of variation are calculated. Methods of mathematical statistics have been adopted to process the simulation results [14].

Results. Modeling with application of the PFC3D software package made it possible to establish the fact that the increase in the intensity of ore mass drawing from the final mine affects the angle of ore release, and accordingly the volume of the drawing figure. During the modeling, numerical data were obtained on the value of the ore discharge angle depending on the intensity of the drawing process and the limit of strength of the ore on uniaxial contact. Based on the established graphical relationships between the value of the ore release angle and its yield strength for uniaxial contact, an analytical expression with a deterministic coefficient $R^{2}=0.924$

$$
\beta=(0.1[\sigma]+75) \cdot I^{0.01-0,0005[\sigma]},
$$

where $[\sigma]$ is the strength limit of the ore for uniaxial compression, $\mathrm{MPa}$; $I$ is intensity of ore mass production drawing, $\mathrm{t} / \mathrm{m}^{2}$ per day.

It is established that the volume of the release figure from a single mine working is determined from the expression

$$
V=\left(\frac{h_{o . l .}}{\operatorname{tg} \beta}+d\right)^{3},
$$

where $h_{o . l}$ is the height of the ore layer above the drawing, m; $d$-diameter of drawing mine working, $\mathrm{m} ; \beta$ is an ore drawing angle, degree.

Based on the research, an analytical expression was obtained of the dependence of the distance between adjacent mine workings, which lie on the same axis, and from which the drawing is conducted in uniform doses simultaneously with the same frequency

$$
l_{h . m v .}=1.365 \sqrt{\frac{\left(d \cdot \operatorname{tg} \beta+h_{o . l .}\right)^{3}}{h_{o . p l} \cdot \operatorname{tg}^{3} \beta}},
$$

where $h_{\text {m.w. }}$ is the height of the ore layer above the drawing, $\mathrm{m}$; $d$ is the diameter of drawing mine working, $\mathrm{m} ; \beta$ is an ore drawing angle, degree.

At the next stage of the research, the influence of the number of outlets on the parameters of the release figure; from the outlets the release is conducted in equal doses at the same frequency, for different heights of the ore layer above the drawings, with respect to the distance between them, which provides critical height ore layer over them [15]. This mode of production is called linear-alternating, which is characterized by the release of uniform doses from all drawing workings along the axis of production of primary delivery with approximately the same frequency $[16,17]$.

Based on the research, an analytical expression was obtained, which determines the volume of the figure of the drawing, during performing from two, three and four mine workings in uniform doses at the same time with the same frequency

$$
V=\left(\frac{h_{o . l .}}{\operatorname{tg} \beta}+d\right)^{3} \cdot N \cdot k,
$$

where $N$ is the number of drawing workings, from which the drawing occurs in uniform doses simultaneously and with the same frequency, pcs; $k$ is the coefficient that takes into account the intensity of the drawing process $\left(I, \mathrm{t} / \mathrm{m}^{2}\right.$ per day), the number of drawing workings, from which the drawing occurs in uniform doses simultaneously and with the same frequency $(N$, pcs.), the strength limit of the ore mass for uniaxial compression $([\sigma])$ and the height of the layer of collapsed ore above the workings $\left(h_{\text {o.l. }}, \mathrm{m}\right)$

$$
k=\frac{1.085^{2} \cdot 1.4^{N} \cdot 0.9884^{[\sigma]} \cdot 1.09^{h_{o . l}} \cdot 0.17}{100}+1 .
$$

According to the results of the research, diagrams of the dependence of the pure ore dilution with application of linear-alternating and uniform sequential modes of drawing from the angle of inclination of the ore deposit have been created (Fig. 1).

After approximation, the power dependencies of the volume of pure ore dilution on the angle of inclination of the ore deposit for different modes of ore drawing were obtained

$$
Q=k \alpha^{b},
$$

where $k$ and $b$ are numerical values that have certain values depending on the different modes of drawing; $\alpha$ is the angle of inclination of the ore deposit, degree: 


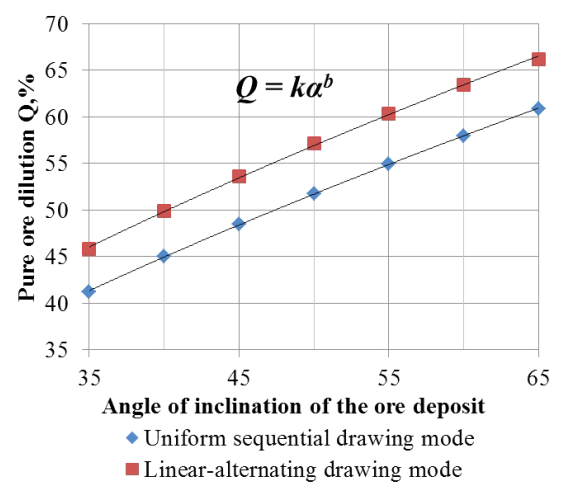

Fig. 1. Diagrams of the dependence of the pure ore dilution on the angle of inclination of the ore deposit during computer modeling

- during linear-sequential drawing mode

$$
Q_{l . s}=4.95 \alpha^{0.6}
$$

- during linear-alternating drawing mode

$$
Q_{l . a}=5.45 \alpha^{0.6} \text {. }
$$

Therefore, the relative pure ore dilution during the linearalternating drawing mode applying will be, $\%$

$$
Q_{\text {rel. }}=\frac{Q_{l . a}-Q_{l . s}}{Q_{l . a}} \cdot 100=\frac{5.45-4.95}{4.95} \cdot 100=10.1,
$$

where $Q_{l . . s}$ is pure ore dilution during linear-sequential drawing mode, $\% ; Q_{l . a}$ is pure ore dilution during linear-alternative drawing mode, $\%$.

Thus, based on the laboratory examinations, it was established that the application of linear-alternating mode of ore drawing will in practical terms increase the extraction rates by at least $10.1 \%$ [18]. The results of the physical modeling of different modes of the ore reserves drawing process from the stoping panel through the workings of the bottom are provided in Table 2 .

Three of the eight stages of physical modeling are shown in Figs. 2 and 3.

From Table 2 it is seen that application of linear-alternating mode of ore drawing during ore deposits mining with a

\begin{tabular}{|c|c|c|c|c|c|c|c|c|c|}
\hline \multirow{2}{*}{ Characteristic } & \multirow{2}{*}{ Dimension } & \multicolumn{8}{|c|}{ Angle of inclination of ore deposit } \\
\hline & & 35 & 40 & 45 & 50 & 55 & 60 & 65 & 75 \\
\hline \multicolumn{10}{|c|}{ Linear-alternating drawing mode } \\
\hline The amount of backfilled ore & $\mathrm{g}$ & 37698 & 33732 & 29654 & 22265 & 21568 & 20965 & 20462 & 30500 \\
\hline The amount of drawing ore & $\mathrm{g}$ & 17262 & 16822 & 15903 & 12718 & 13023 & 13296 & 13544 & 24431 \\
\hline Relative dilution & $\%$ & 45.79 & 49.87 & 53.63 & 57.12 & 60.38 & 63.42 & 66.19 & 80.10 \\
\hline Relative ore losses & $\%$ & 54.21 & 50.13 & 46.37 & 42.88 & 39.62 & 36.58 & 33.81 & 19.90 \\
\hline \multicolumn{10}{|c|}{ Uniform and sequential drawing mode } \\
\hline The amount of backfilled ore & $\mathrm{g}$ & 37584 & 33698 & 29620 & 22218 & 21517 & 20898 & 20524 & 30525 \\
\hline The amount of drawing ore & $\mathrm{g}$ & 15492 & 15164 & 14366 & 11507 & 11817 & 12106 & 12485 & 23993 \\
\hline Relative dilution & $\%$ & 41.22 & 45.00 & 48.50 & 51.79 & 54.92 & 57.93 & 60.83 & 78.60 \\
\hline Relative ore losses & $\%$ & 58.78 & 55.00 & 51.50 & 48.21 & 45.08 & 42.07 & 39.17 & 21.40 \\
\hline
\end{tabular}

The main indicators of pure ore dilution when applying different drawing modes

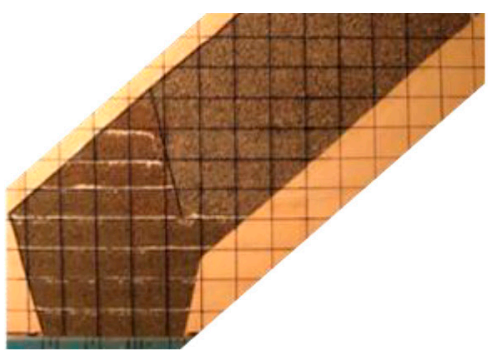

$a$

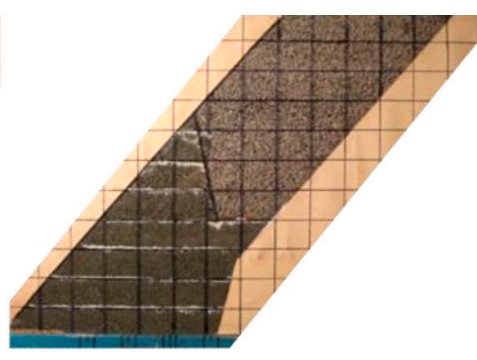

b

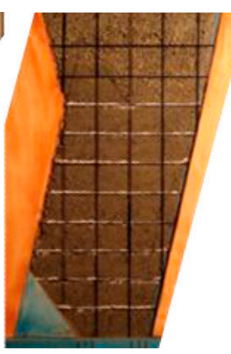

$c$

Fig. 2. Type of physical models of the stoping panel after being filled with bulk material:

$a$-angle of inclination $40^{\circ} ; b$ - angle of inclination $50^{\circ} ; c$-angle of inclination $75^{\circ}$

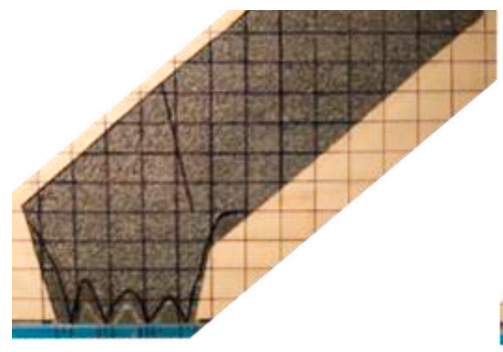

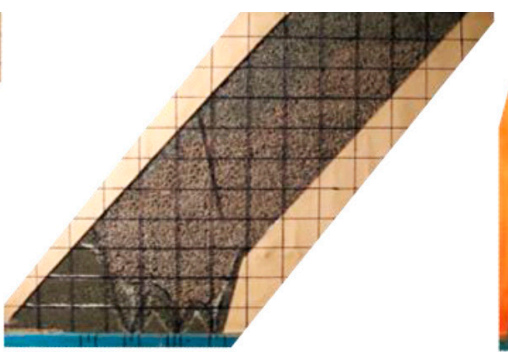

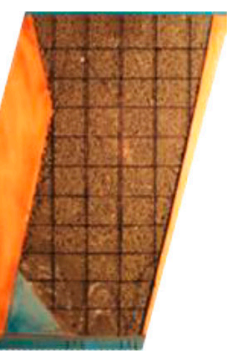

$c$

Fig. 3. Type of physical models of the stoping panel after the last dose of pure ore drawing:

$a$ - angle of inclination $40^{\circ} ; b$ - angle of inclination $50^{\circ} ; c-$ angle of inclination $75^{\circ}$ 
range of angles of inclination in the range of $35-65^{\circ}$, allows extracting pure ore from 45.8 to $66.2 \%$, which is an average of $4.6 \%$ (abs.) more in comparison with a uniformly consecutive mode of drawing. Furthermore, with an increasing angle of inclination of the ore deposit from 65 to $90^{\circ}$, the difference between the extraction rates at different modes of drawing decreases. This is due to the fact that the volume of the "total figure of drawing" of ore from several outlets during linear-alternating mode application is more than the sum of the volumes of figures of drawing from the same outlets during uniform sequential mode application and provides increased extraction of ore from the stagnant zone of the lying side of the ore deposit without additional costs for the workings formation.

According to Table 2, the graphical dependencies were developed for the of pure ore dilution on the angle of inclination of the ore deposit for different modes of drawing with the selection of the most common range of angles of inclination of ore deposits for the Kryvbas (35-65 ) (Fig. 4).

After approximation with the help of obtained degree, dependencies of the volume of pure ore dilution on the angle of inclination of the ore deposit for different modes of ore drawing were developed

$$
Q=k \alpha^{b},
$$

where $k$ and $b$ are numerical values that have certain values depending on the different modes of drawing; $\alpha$ is an angle of inclination of ore deposit, degree:

- during linear-sequential drawing mode

$$
Q_{l . s}=3.35 \alpha^{0.7} \text {; }
$$

- during linear-alternating drawing mode

$$
Q_{l . a}=3.05 \alpha^{0.7} .
$$

Then, the relative pure ore dilution during application of the linear-alternating mode of drawing will be, $\%$

$$
Q_{\text {rel. }}=\frac{Q_{l . s}-Q_{l . a}}{Q_{l . s}} \cdot 100=\frac{3.35-3.05}{3.05} \cdot 100=9.8
$$

where $Q_{l . s .}$ is pure ore dilution during linear-sequential drawing mode, $\% ; Q_{\text {l.a. }}$ is pure ore dilution during linear-alternative drawing mode, $\%$.

Thus, on the basis of the laboratory examinations, it was established that application of linear-alternating mode of ore drawing will allow increasing the extraction rate by at least $9.8 \%$ in practical conditions.

\section{Conclusions.}

1. Based on numerical modeling, it is established that the best rates of pure ore dilution in the amount of 46-66\%, depending on the angle of inclination of the ore deposit, which varies from 35 to $65^{\circ}$, have been achieved as a result of ore

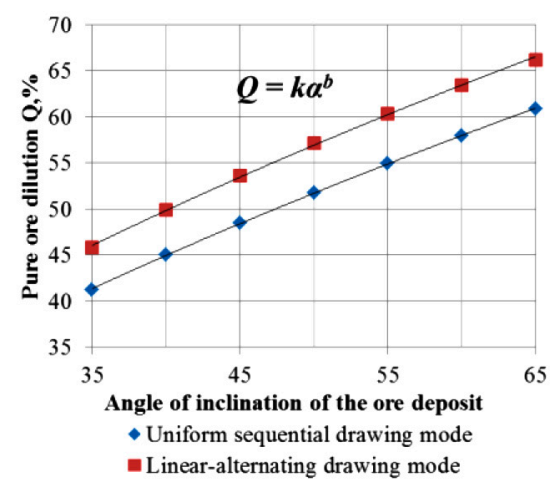

Fig. 4. Diagrams of the dependence of the pure ore dilution on the angle of inclination of the ore deposit during physical modeling drawing by linear-alternating mode. It is characterized by drawing in uniform doses simultaneously from each outlet along the axis of the initial delivery, with approximately the same frequency, alternately or alternately-stepwise over the area of the bottom of the receiving horizon. It is also established that reducing the yield strength of ore for uniaxial compression and increasing the intensity of ore mass from 1.5 to $10.5 \mathrm{t} / \mathrm{m}^{2}$ per day, in the process of mining of mineral deposits at a depth of 1400-1500 m, we reduce the angle of ore drawing from 84 to $76^{\circ}$, which allows increasing the distance between mine workings to $7.5 \mathrm{~m}$ and up to $27 \%$ reduce the cost of their drivage.

2. The results of physical modeling of the ore drawing process on equivalent materials allowed establishing that the rates of pure ore dilution during applying the linear-alternating mode increase by $10 \%$ compared to the uniform sequential mode, so the proportional increase in the diameter of outlets and the distance between them and delivery, queue of the ore drawing, from the hanging to the lying side of the ore deposit and vice versa, does not affect the extraction rates, as their difference does not exceed $0.6 \%$.

3 . The established regularities of change in ore dilution indicators from drawing intensity, ore compression strength limits, height of collapsed ore layer and the number of drawing workings, their diameter and distance between them allowed substantiating rational parameters of structural elements of ore drawing and delivery technological scheme.

4. On the basis of the established regularities, the technological schemes of mining methods variants of subsurface collapse which will provide reduction of losses level up to $4.6 \%$ and ore weakening up to $5.2 \%$, as well as improvement of the absolute quality of the extracted ore mass, up to $1.5 \%$ in the course of underground mining of high-grade iron-ores in complicated geomechanical conditions of deep horizons are developed.

\section{References.}

1. Yakubov, N. M. (2015). Mineral resources base of ferrous metallurgy today and the prospects for the development of the steel industry in Uzbekistan. Economy in the Industry, (2), 119123. https://doi.org/10.17073/2072-1633-2015-2-119-123.

2. Smirnov, A.Ya., Yevtekhov, Ye.V., \& Yevtekhov, V.D. (2014). Geological structure of hematite quartzite deposits in Kryvyi Rih basin. Naukovyi Visnyk Natsionalnoho Hirnychoho Universytetu, (2), 17-22.

3. Stupnik, M., Kolosov, V., Pysmennyi, S., \& Kostiantyn, K. (2019). Selective mining of complex stuctured ore deposits by open stope systems. E3S Web of Conferences, 123, 01007. https://doi.org/10.1051/e3sconf/201912301007.

4. Pysmennyi, S., Brovko, D., Shwager, N., Kasatkina, I., Paraniuk, D., \& Serdiuk, O. (2018). Development of complexstructure ore deposits by means of chamber systems under conditions of the Kryvyi Rih iron ore field. Eastern-European Journal of Enterprise Technologies, 5(1(95)), 33-45. https:// doi.org/10.15587/1729-4061.2018.142483.

5. Kosenko, A.V. (2018). Ways to increase the efficiency of development of deposits of natural high-grade iron ores at great depths. Hirnychyi Visnyk, (103), 70-75.

6. Stupnik, M., Kalinichenko, O., Kalinichenko, V., Pysmennyi, S., \& Morhun, O. (2018). Choice and substantiation of stable crown shapes in deep-level iron ore mining. Mining of Mineral Deposits, 12(4), 56-62. https://doi.org/10.15407/ mining12.04.056.

7. Stupnik, M.I., Kalinichenko, V.O., Pysmennyi, S.V., \& Kalinichenko, O.V. (2018). Determining the qualitative composition of the equivalent material for simulation of Kryvyi Rih iron ore basin rocks. Naukovyi Visnyk Natsionalnoho Hirnychoho Universytetu, (4), 21-27. https://doi.org/10.29202/ nvngu/2018-4/4. 
8. Sosnovskiy, L. A., Zhuravkov, M. A., Sherbakov, S. S., Bogdanovich, A. V., Makhutov, N.A., \& Zatsarinnyi, V. V. (2015). Fundamental last of the ultimate state of objects at the effects of multi parameter power factors and thermodynamic environment. Part II. Mechanics of Machines, Mechanisms and Materials, 4(33), 76-92.

9. Mashchenko, V.A., Khomenko, O. Ye., \& Kvasnikov, V.P. (2020). Thermodynamic aspect of rock destruction. Naukovyi Visnyk Natsionalnoho Hirnychoho Universytetu, (1), 25-30. https://doi.org/10.33271/nvngu/2020-1/025.

10. Laptev, V. V. (2019). Numerical modelling of fragmented mined rock flow during ore drawing using the ROCKY DEM programme. Vestnik MGTU, 22(1), 149-157. https://doi. org/10.21443/1560-9278-2019-22-1-149-157.

11. Kononenko, M., Khomenko, O., Sudakov, A., Drobot, S., \& Lkhagva, T. (2016). Numerical modelling of massif zonal structuring around underground working. Mining Of Mineral Deposits, 10(3), 101-106. https://doi.org/10.15407/mining10.03.101.

12. Golik, V.I., Lukyanov, V.G., \& Komashchenko, V.I. (2016). Modeling ore quality using ore caving technique. Bulletin of the Tomsk Polytechnic University. Geo Assets Engineering. 327(10), 6-12.

13. Kosenko, A. V., \& Tarasiutin, V. M. (2018). Research on technological process of ore production on the basis of physical modeling. Vcheni zapysky Tavriiskoho natsionalnoho universytetu imeni V.I.Vernadskoho: Seriia "Tekhnichni nauky", 29(68(4(2)), 73-79.

14. Sdvyzhkova, O., Babets, D., Kravchenko, K., \& Smirnov, A. (2015). Rock state assessment at initial stage of longwall mining in terms of poor rocks of Western Donbass. New Developments in Mining Engineering 2015, 65-70. https://doi. org/10.1201/b19901-13.

15. Khomenko, O., Kononenko, M., \& Bilegsaikhan, J. (2018). Classification of Theories about Rock Pressure. Solid State Phenomena, 277, 157-167. https://doi.org/10.4028/ www.scientific.net/ssp.277.157.

16. Khomenko, O., \& Kononenko, M. (2019). Geo-energetics of Ukrainian crystalline shield. Naukovyi Visnyk Natsionalnoho Hirnychoho Universytetu, (3), 12-21. https://doi. org/10.29202/nvngu/2019-3/3.

17. Khomenko, O., Kononenko, M., \& Petlovanyi, M. (2015). Analytical modeling of the backfill massif deformations around the chamber with mining depth increase. New Developments in Mining Engineering 2015, 265-269. https://doi. org/10.1201/b19901-47.

18. Khomenko, O., Kononenko, M., \& Netecha, M. (2016). Industrial research into massif zonal fragmentation around mine workings. Mining of Mineral Deposits, 10(1), 50-56. https://doi.org/10.15407/mining 10.01.050.

\section{Удосконалення систем підповерхового обвалення при розробці багатих залізних руд}

\section{А. В. Косенко}

Інститут фізики гірничих процесів Національної академії наук України, м. Дніпро, Україна, e-mail: AndreyVladimirovich@email.ua

Мета. Удосконалити системи підповерхового обвалення руди та вмісних порід при розробці покладів багатих залізних руд шляхом застосування раціонального режиму та інтенсифікації технологічного процесу випуску.

Методика. Включала аналіз наукової літератури, проектної й конструкторської документації та практики розробки покладів багатих залізних руд у складних геомеханічних умовах глибоких горизонтів шахт для встановлення формування принципово нових основ наукових і проектних рішень з раціонального видобутку корисних копалин; чисельне (за допомогою спеціального комп'ютерного програмного комплексу «РFC 3D») і фізичне (на основі використання об'ємних фізичних моделей та еквівалентних матеріалів) моделювання випуску руди, для виявлення закономірностей процесу вилучення руди в залежності від гірничо-геологічних і гірничотехнічних умов розробки покладів, а також фізико-механічних властивостей подрібненої рудної маси.

Результати. Встановлені закономірності зміни якісних і кількісних показників вилучення в залежності від інтенсивності технологічного процесу випуску та фізико-механічних властивостей руди за допомогою чисельного й фізичного моделювання. Отримані закономірності дали змогу обгрунтувати раціональні параметри конструктивних елементів технологічної схеми випуску й доставки руди. Розроблено лінійно-почерговий режим випуску, шо забезпечує: збільшення вилучення чистої руди до $10 \%$; зменшення втрат руди до 4,6 \%; зменшення збіднення до $5,2 \%$; підвищення до $1,5 \%$ абсолютної якості видобутої рудної маси.

Наукова новизна. Встановлені степеневі залежності зміни кута випуску руди від інтенсивності процесу випуску й межі міцності руди на одновісне стискання, а також залежності збільшення об'єму фігури випуску, при застосуванні лінійно-почергового режиму випуску, від інтенсивності процесу випуску, висоти шару обваленої руди та межі міцності руди на одновісне стискання.

Практична значимість. Розроблено лінійно-почерговий режим випуску руди, реалізація якого на практиці дозволяє підвищити якісні й кількісні показники вилучення та виключити людський фактор при дотриманні планограми випуску.

Ключові слова: багаті залізні руди, підповерхове обвалення, показники вилучення, втрати руди, збіднення, випуск руди

\section{Совершенствование систем подэтажного обрушения при разработке богатых железных руд}

\section{A. В. Косенко}

Институт физики горных процессов Национальной академии наук Украины, г. Днепр, Украина, e-mail: AndreyVladimirovich@email.ua

Цель. Усовершенствовать системы подэтажного обрушения руды и вмещающих пород при разработке залежей богатых железных руд путём применения рационального режима и интенсификации технологического процесса выпуска.

Методика. Включала анализ научной литературы, проектной и конструкторской документации и практики разработки залежей богатых железных руд в сложных геомеханических условиях глубоких горизонтов шахт для установления формирования принципиально новых основ научных и проектных решений по рациональной добыче полезных ископаемых; численное (с помощью специального компьютерного программного комплекса «PFC 3D») и физическое (на основании использования объемных физических моделей и эквивалентных материалов) моделирование выпуска руды, для выявления закономерностей процесса извлечения руды в зависимости от горно-геологических и горнотехнических условий разработки залежей, а также физико-механических свойств отбитой рудной массы. 
Результаты. Установлены закономерности изменения качественных и количественных показателей извлечения в зависимости от интенсивности технологического процесса выпуска и физико-механических свойств руды с помощью численного и физического моделирования. Полученные закономерности позволили обосновать рациональные параметры конструктивных элементов технологической схемы выпуска и доставки руды. Разработан линейно-поочерёдный режим выпуска, который обеспечит: увеличение извлечения чистой руды до $10 \%$; уменьшение потерь руды до $4,6 \%$; уменьшение разубоживания руды до 5,2 \%; повышение до 1,5\% абсолютного качества добытой рудной массы.

Научная новизна. Установлены степенные зависимости изменения угла выпуска руды от интенсивности процесса выпуска и предела прочности руды на одноосное сжатие, а также зависимости увеличения объема фигуры выпуска, при применении линейно-поочерёдного режима выпуска, от интенсивности процесса выпуска, высоты слоя обрушенной руды и предела прочности руды на одноосное сжатие.

Практическая значимость. Разработан линейно-поочерёдный режим выпуска руды, реализация которого на практике позволяет повысить качественные и количественные показатели извлечения и исключить человеческий фактор при соблюдении планограмм выпуска.

Ключевые слова: богатые железные руды, подэтажное обрушение, показатели извлечения, потери руды, разубожсивание, выпуск руды

Recommended for publication by O. M. Molchanov, Doctor of Technical Sciences. The manuscript was submitted 27.07.20. 